\title{
$\mu$-Opioid Agonists Inhibit Spinal Trigeminal Substantia Gelatinosa Neurons in Guinea Pig and Rat
}

\author{
Timothy J. Grudt ${ }^{1.2}$ and John T. Williams ${ }^{1}$ \\ 'Vollum Institute and 'Department of Cell Biology and Anatomy, Oregon Health Sciences University, Portland, Oregon \\ 97201
}

The actions of opioid agonists in the substantia gelatinosa are important for their antinociceptive effects. In order to identify possible mechanisms underlying opioid actions in the substantia gelatinosa, the pre- and postsynaptic effects of opioid agonists on neurons of the substantia gelatinosa were examined using a brain slice preparation. Intracellular recordings were made from neurons of the substantia gelatinosa of the spinal trigeminal nucleus pars caudalis in guinea pig and rat. To correlate morphology and electrophysiology, neurons were filled with biocytin and visualized using HRP. The majority of neurons $(86 \%)$ were hyperpolarized by [Met] ${ }^{5}$ enkephalin (ME), and this was mimicked by the $\mu$-opioid agonist (D-Ala ${ }^{2}, \mathrm{~N}$-Me-Phe ${ }^{4}, \mathrm{Gly}^{5}$-ol)enkephalin (DAMGO) but not the $\delta$-opioid agonist (D-Pen ${ }^{2,5}$ )enkephalin (DPDPE). Naloxone (300 nM) shifted the DAMGO dose-response 213-fold to the right, giving an estimated $K_{D}$ of 1.4 nM. Under voltage clamp, the ME current reversed polarity at the potassium equilibrium potential, indicating the hyperpolarization was due to an increase in potassium conductance. EPSPs mediated by glutamate were evoked by stimulating the spinal trigeminal tract, which contains the primary afferent fibers that synapse in the spinal trigeminal nucleus. The excitation produced by stimulating the spinal trigeminal tract was greatly enhanced in the presence of glycine and $\mathrm{GABA}_{\mathrm{A}}$ receptor antagonists, indicating that local inhibitory circuitry is activated by exciting the primary afferents. The EPSPs were reduced by $\mu$ - but not $\delta$-opioid receptor activation. The degree of inhibition varied from 0 to $100 \%$. These results indicate that opioid agonists cause inhibition in the substantia gelatinosa by both pre- and postsynaptic actions.

[Key words: substantia gelatinosa, $\mu$-opioid, presynaptic inhibition, DAMGO, naloxone, GABA, glycine, morphology]

The substantia gelatinosa (SG), lamina 2 of both the spinal trigeminal nucleus pars caudalis and the gray matter of the dorsal horn of the spinal cord, is the primary site of termination of primary afferents that respond to noxious stimuli (I ight and Perl, 1979; Sugiura et al., 1986). The SG itself has been hypothesized to form a processing network (Gobel, 1978; Bennett et al., 1980) and there are connections between the SG and

\footnotetext{
Received June 1, 1993; revised Aug. 12, 1993; accepted Aug. 26, 1993.

We thank Dr. Edwin McClesky and Dr. Charles Chavkin for valuable comments on the manuscript. This work was supported by NIH Grants DA08163, DA00141, and DA07262.

Correspondence should be addressed to John $T$. Williams, Vollum Institute, Oregon Health Sciences I Jniversity, I -474, 3181 SW Sam Jackson Road, Portland OR 97201.

Copyright (C) 1994 Society for Neuroscience $0270-6474 / 94 / 141646-09 \$ 05.00 / 0$
}

nearby laminae (Gobel et al., 1980; Light and Kavookjian, 1988), which contain neurons projecting to rostral areas of the brain (Giesler et al., 1976). Work in vivo has implicated the SG as being an important site for the analgesic actions of administered opioid agonists (Duggan et al., 1977; Johnson and Duggan, 1981). In addition, the $\mathrm{SG}$ contains opioid peptides that may play a role in endogenous control of pain (Merchenthaler et al., 1986).

There are several possible sites of action of opioid agonists within the SG. In rat spinal cord slices, [Met] ${ }^{5}$-enkephalin (ME) hyperpolarizes SG neurons by increasing potassium conductance (Yoshimura and North, 1983). In addition to a postsynaptic action, there is also evidence that opioid agonists acting presynaptically inhibit synaptic transmission between primary afferent fibers and neurons in the dorsal horn upon which they synapse (MacDonald and Nelson, 1978; Jeftinija, 1988).

The horizontal slice of the spinal trigeminal nucleus pars caudalis is suited to the study of the function of $\mathrm{SG}$ neurons for several reasons. The spinal trigeminal tract is clearly identifiable on the latcral bordcr of the horizontal slice, which makes it possible to stimulate the primary afferent fibers selectively. The dendrites of SG neurons extend rostrocaudally (Light et al., 1979; Woolf and Fitzgerald, 1983), and are therefore preserved in the horizontal slice, which maximizes synaptic contacts and responses to applied agonists. This preparation was used to identify and characterize the pre- and postsynaptic actions of opioid agonists. In the process, the transmitter mediating synaptic transmission between primary afferent fibers and SG cells was identified and evidence for inhibitory circuitry activated by primary afferent stimulation was obtained. Both guinea pig and rat were used to compare opioid actions in the $\mathrm{SG}$ in different species.

Some of the results have been presented in abstract form (Grudt and Williams, 1991).

\section{Materials and Methods}

Horizontal brain slices $(300 \mu \mathrm{m})$ containing the spinal trigeminal nucleus pars caudalis were made from male Hartley guinea pigs $(180-250 \mathrm{gm}$, 90 animals) or male Wistar rats (140-180 gm, 65 animals; Fig. $1 A$ ). Briefly, a block of brainstem including the caudal part of the medulla was placed in a vibratome containing a $4^{\circ} \mathrm{C}$ oxygenated physiological saline solution. Slices (two or three) containing the substantia gelatinosa were taken from near the dorsal surface of the medulla. A single slice was placed in a tissue bath through which flowed warmed $\left(35^{\circ} \mathrm{C}\right)$ physiological saline at a rate of $1.5 \mathrm{ml} / \mathrm{min}$. The physiological saline consisted of (in mM) NaCl, 126; KCl, 2.5; $\mathrm{NaH}_{2} \mathrm{PO}_{4}, 1.2 ; \mathrm{MgCl}_{2}, 1.3 ; \mathrm{CaCl}_{2}, 2.4$; glucose, 11; and $\mathrm{NaHCO}_{3}, 25$; and was gassed with $95 \% \mathrm{O}_{2}, 5 \% \mathrm{CO}_{2}$.

The SG in both guinea pig and rat is clearly visible in a horizontal slice of the spinal trigeminal nucleus par caudalis (Fig. $1 B, C$ ). It forms a translucent band medial to the spinal trigeminal tract, which enters the brain stem $5-6 \mathrm{~mm}$ rostral of the spinal trigeminal nucleus pars 
A.

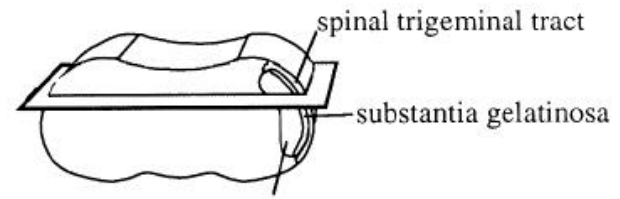

spinal trigeminal nucleus pars caudalis

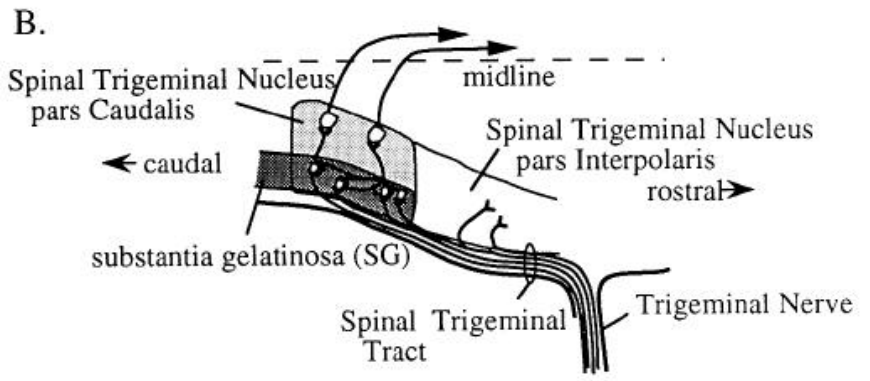

C.

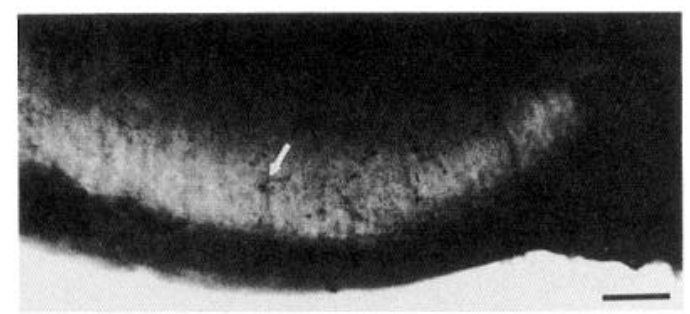

Figure 1. Anatomy of the SG of the spinal trigeminal nucleus pars caudalis. $A, \mathrm{~A}$ transversely cut section of brainstem containing the spinal trigeminal nucleus pars caudalis. The shaded area is intended to show the plane of a horizontal section. $B$, A horizontal slice in schematic form. $C$, A photograph of a horizontal slice at $40 \times$. The orientation of the slice is the same in $B$ and $C$. The translucent area is the substantia gelatinosa. The arrow points to the cell shown in Figure $9 D$. Scale bar, $200 \mu \mathrm{m}$.

caudalis as the trigeminal nerve and travels at the lateral edge of the slice. Slices were cut to include $3-4 \mathrm{~mm}$ of the spinal trigeminal tract rostral of the SG.

Intracellular recordings were made from SG neurons (94 in guinea pig and 63 in rat) using $50-100 \mathrm{M} \Omega$ electrodes containing $2 \mathrm{M} \mathrm{KCl}$. Drugs were applied by switching from the control solution to one that differed from the control solution only in the presence of the added drug. Input resistances were estimated by injecting a known amount of current and measuring the resulting voltage change. Synaptic potentials were evoked by passing current for $0.5 \mathrm{msec}$ between two tungsten wires placed in the slice. For voltage-clamp experiments, membrane currents were recorded using a single-electrode, voltage-clamp amplifier (Axoclamp 2A) using switching frequencies between 3 and $5 \mathrm{kHz}$. Dose response curves were fit using a logistic equation with the LevenbergMarquardt algorithm (Kaleida Graph 2.13). $\mathrm{EC}_{50}$ values were determined from this fit. Numerical data is presented as the mean \pm SEM.

SG neurons in 34 slices were filled with biocytin for subsequent identification. Biocytin was dissolved in $2 \mathrm{M} \mathrm{KCl}$ buffered with Tris ( $\mathrm{pH}$ 7.3) and used as the pipette solution. Recording times with biocytin ranged from 1 to $6 \mathrm{hr}$. The slices were fixed in a solution of $2 \%$ formaldehyde and $15 \%$ picric acid in a phosphate buffer $(\mathrm{pH} 7.2)$. Following fixation, the slices were incubated successively in hydrogen peroxide $(0.01 \%)$ and Triton $\mathrm{X}-100(0.3 \%)$, washing with $0.1 \mathrm{M}$ phosphate buffer $(\mathrm{pH} 7.0)$ before and after each incubation. The slices were then reacted with an avidin-biotin HRP complex (Vector Laboratories, Standard Peroxidase Kit) and washed with phosphate buffer, and the cells visualized with diaminobenzidine (DAB). The soma and dendrites of the cells were characterized after clearing the slices with dimethyl sulfoxide. In most cases, the locations of the cells were noted after drying and clearing the slices with methyl salicylate.

Drugs used (and sources) were as follows: DL-2-amino-5-phosphonovaleric acid (APV; Sigma), bestatin (Cambridge), (-)bicuculline meth-
A.

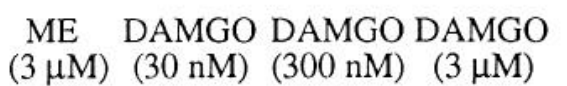

B.
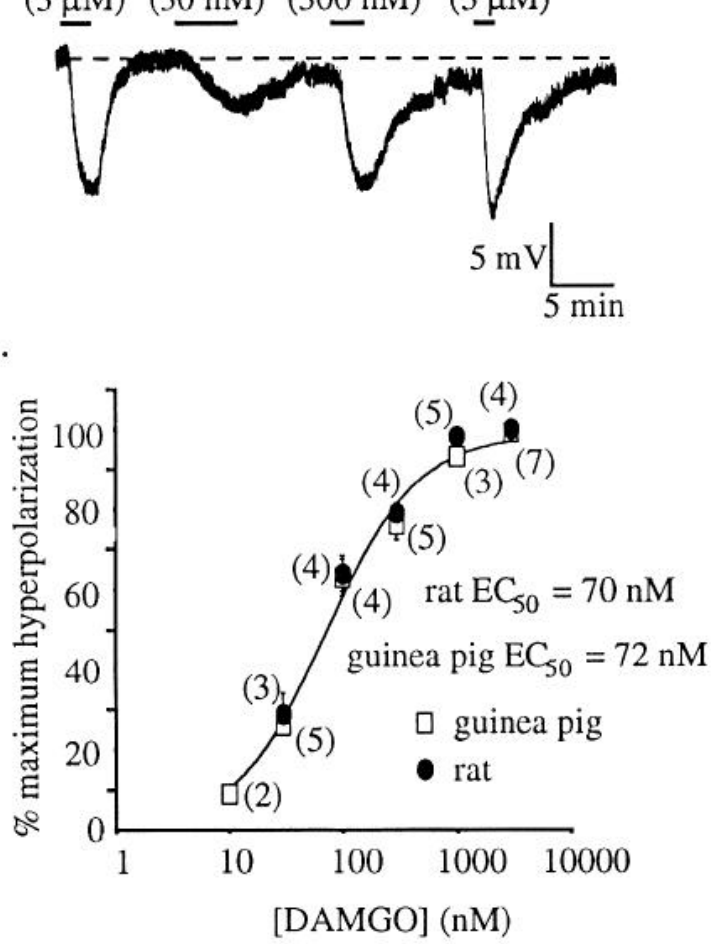

Figure 2. $\mu$-Opioid receptor activation hyperpolarizes guinea pig and rat SG neurons. $A$, Hyperpolarization of a guinea pig SG neuron by $[\mathrm{Met}]^{5}$ enkephalin $(M E)$. The hyperpolarization was mimicked by the $\mu$-opioid agonist DAMGO in a dose-dependent matter. $B$, Dose-response curve for the hyperpolarization of guinea pig and rat SG neurons by DAMGO. In this and other figures, the number of cells used to construct each data point is shown in parentheses, with those for rat to the left and guinea pig to the right of the curve. The error bars shown in this and other figures are SE values. The curve shown was fitted to the guinea pig data.

iodide (Sigma), biocytin (Sigma), 6-cyano-7-nitroquinoxaline-2,3-dione (CNQX; Research Biochemicals, Inc.), (D-Ala ${ }^{2}, N-\mathrm{Me}^{-\mathrm{Phe}^{4}, \mathrm{Gly}^{5}-}$ ol)enkephalin (DAMGO; Sigma), (D-Pen ${ }^{2.5}$ enkephalin (DPDPE; Sigma), DAB (Sigma), [Met] ${ }^{5}$-enkephalin (ME; Sigma), picrotoxin (Sigma), strychnine (Sigma), tetrodotoxin (TTX; Sigma), DL-thiorphan (BACHEM). Bestatin $(20 \mu \mathrm{M})$ and DL-thiorphan $(2 \mu \mathrm{M})$ were included in all ME solutions to inhibit peptidase activity (Williams et al., 1987).

\section{Results}

\section{Opioid agonists increase potassium conductance}

Guinea pig. Intracellular recordings were made from guinea pig SG neurons in a horizontal slice of the spinal trigeminal nucleus pars caudalis. Figure $1 C$ shows a horizontal slice of the spinal trigeminal nucleus pars caudalis with the translucent SG clearly visible. The average resting membrane potential was $-68.6 \pm$ $0.8 \mathrm{mV}(n=94)$ and the input resistance varied from 90 to 600 $\mathrm{M} \Omega$. Neurons were not spontaneously active, resting $10-15 \mathrm{mV}$ negative to threshold.

In guinea pig SG, 78 of 91 neurons $(86 \%)$ were hyperpolarized by $\mathrm{ME}(3 \mu \mathrm{M}$, Fig. $2 A)$. The magnitude of the hyperpolarization varied from a few millivolts to $35 \mathrm{mV}$ (mean, $15.1 \pm 0.95 \mathrm{mV}$ ). The response to $\mathrm{ME}(3 \mu \mathrm{M})$ was reproducible and remained stable throughout a 4 or $5 \mathrm{hr}$ recording.

Since ME activates both $\mu$ - and $\delta$-opioid receptors, the receptor type mediating the hyperpolarization by ME was determined using specific agonists. The ME hyperpolarization was mim- 




Figure 3. Naloxone shifts the guinea pig DAMGO dose-response curve to the right. This shift gives an estimated $K_{D}$ for naloxone of $1.4 \mathrm{nM}$.

icked by the $\mu$-opioid receptor agonist DAMGO (10 nM to 3 $\mu \mathrm{M}, n=41$; Fig. $2 A)$ but not by the $\delta$-opioid receptor agonist DPDPE $(1 \mu \mathrm{M}, n=9)$. The maximum response to DAMGO was equal to that of ME with a mean DAMGO hyperpolarization of $17.7 \pm 1.5 \mathrm{mV}$. The dose-response curve for DAMGO is shown in Figure $2 B$ and has an $\mathrm{EC}_{50}$ of $72 \pm 12 \mathrm{nM}$.

Naloxone shifted the DAMGO dose-response curve to the right (Fig. 3). The $K_{D}$ of naloxone for the site at which DAMGO acted was estimated using the equation $K_{D}=$ [naloxone]/DR 1) where DR, the dose ratio, is the magnitude of the shift (Kosterlitz and Watt, 1968). Naloxone (300 nM) shifted the DAMGO dose-response 213 -fold to the right $\left(\mathrm{EC}_{50}=15.3 \pm 5.3 \mu \mathrm{M}\right)$, giving an estimated $K_{D}$ of $1.4 \mathrm{~nm}$.

In voltage clamp, ME activated a current that was associated with an increase in membrane conductance (Fig. 4A). In 2.5 $\mathrm{mM} \mathrm{K}^{+}$, the reversal potential of the current was $-109 \pm 0.3$ $\mathrm{mV}(n=4)$, near the reversal potential of $-107 \mathrm{mV}$ predicted for a potassium conductance from the Nernst equation. When the external potassium concentration was increased, the reversal potential shifted to the right (Fig. $4 B$ ). Plotting the reversal potential versus $\left.\log \left(\left[\mathrm{K}^{+}\right]_{o / / K}{ }^{+}\right]_{i}\right)$ for each cell yielded straight lines with a slope of $52.1 \pm 3.5(n=4)$. These results indicate that opioid agonists activate an in channel that is selectively permeable to potassium ions. In addition, the similarity of the experimentally observed reversal potential to the predicted potassium equilibrium potential indicates that the space clamp of the current induced by opioid agonists was adequate.

Rat. Intracellular recordings were made from $63 \mathrm{SG}$ neurons of rat spinal trigeminal nucleus pars caudalis. The average resting membrane potential was $-62.8 \pm 3.8 \mathrm{mV}(n=6)$ and the input resistance ranged from 70 to $500 \mathrm{M} \Omega$. As in the guinea pig, SG neurons in rat were not spontaneously active.

ME (3 $\mu \mathrm{M})$ hyperpolarized 43 of 48 rat SG neurons (90\%) $13.7 \pm 1.3 \mathrm{mV}$. The hyperpolarization was identical to that seen in the guinea pig in that it was due to an increase in potassium conductance and was mimicked by the $\mu$-opioid receptor agonist DAMGO ( $30 \mathrm{nM}$ to $3 \mu \mathrm{M}, n=8$ ) but not the $\delta$-opioid receptor agonist DPDPE $(n=5)$. The $\mathrm{EC}_{50}$ for the DAMGO hyperpolarization in rat was $70 \pm 12 \mathrm{~nm}$ (Fig. $2 B$ ).

\section{Opioid agonists inhibit synaptic potentials}

Synaptic potentials were evoked by electrically stimulating the primary afferent fibers that travel in the spinal trigeminal tract


Figure 4. ME increases potassium conductance. $A$, Current-voltage curves were constructed under voltage clamp by holding the cell at -60 $\mathrm{mV}$ and stepping to the potentials indicated for $500 \mathrm{msec}$. The external potassium concentration is $2.5 \mathrm{mM}$. ME causes a current that is outward near the holding potential and inward at negative potentials. $B$, MF currents obtained by subtracting the current in ME from the control current. Increasing the external potassium concentration shifts the reversal potential for the current increased by $\mathrm{ME}$.

(see Fig. $1 B$ ). The tract was stimulated, at submaximal intensity, $0.5-2.0 \mathrm{~mm}$ rostral to the $\mathrm{SG}$ to prevent direct excitation of SG neurons.

Guinea pig. In 56 of 68 guinea pig SG cells (82\%), a single stimulus produced a fast EPSP with a latency of $1.5-10 \mathrm{msec}$ following the stimulus. The average amplitude was $8.6 \pm 0.7$ $\mathrm{mV}(n=22)$. In 20 cells, a single EPSP was present that peaked within 30 msec of its onset and decayed completely within 100$200 \mathrm{msec}$ (e.g., Fig. 5A). In 25 cells, additional depolarizing synaptic potentials of longer latency were present (Fig. $5 B$ ). In two cells, a single stimulus produced a barrage of synaptic potentials lasting 2-3 sec (Fig. 5C). In the remainder of the cells, it was not possible to distinguish additional synaptic potentials from spontaneous synaptic potentials present in the absence of stimulation.

Glutamate mediates the EPSP. The AMPA glutamate receptor antagonist CNQX $(10 \mu \mathrm{M})$ reduced the EPSP by $89.7 \pm 1.9 \%$ $(n=9)$, and in two cells the NMDA glutamate receptor antagonist APV $(100 \mu \mathrm{M})$ blocked $81 \%$ and $70 \%$ of the remaining CNQX-insensitive EPSP (Fig. 6A).

$G A B A$ and glycine mediate local inhibition. In three of four cells with a single EPSP or an EPSP followed by a few polysynaptic EPSPs, addition of the $\mathrm{GABA}_{\mathrm{A}}$ antagonist picrotoxin $(100 \mu \mathrm{M})$ and the glycine antagonist strychnine $(1 \mu \mathrm{M})$ resulted in a burst of synaptic potentials, in response to a single stimulus, 

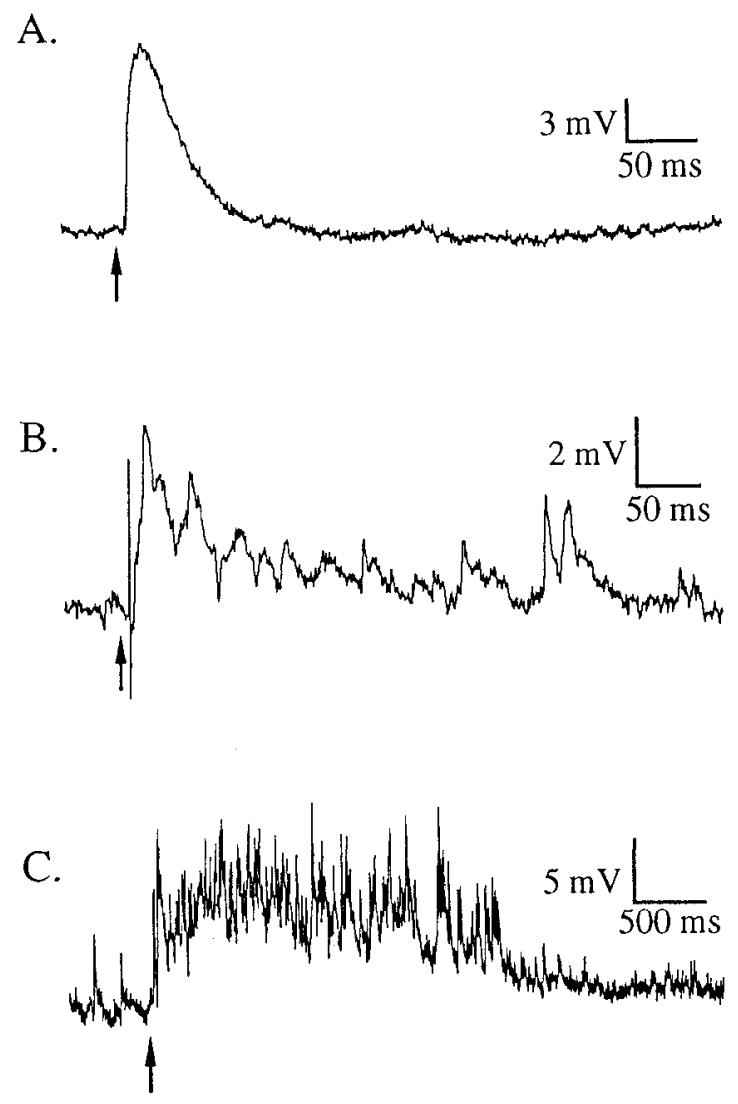

Figure 5. Synaptic potentials evoked by focal electrical stimulation in the spinal trigeminal tract rostral of the SG. The arrows indicate the time of the stimulus. $A$, A single monosynaptic EPSP. $B$, An EPSP followed by additional depolarizing synaptic potentials. $C$, A single stimulus evokes a burst of synaptic potentials. Note the different time scale in $C$.

that depolarized the cells $10-30 \mathrm{mV}$ and lasted $1-3 \mathrm{sec}$ (Fig. $6 B)$. In one cell, CNQX $(10 \mu \mathrm{M})$ blocked both the initial EPSP and the burst. In 2 of 12 cells with stable membrane potentials, addition of picrotoxin and strychnine resulted in spontaneous 20-30 mV depolarizations lasting 2-5 sec that occurred with a frequency of $2-3 / \mathrm{min}$. CNQX $(10 \mu \mathrm{M})$ blocked the spontaneous depolarization in the one cell where it was applied.

These results suggest that $\mathrm{GABA}_{\mathrm{A}}$ and glycine receptors mediate inhibition following stimulation of excitatory primary afferent fibers. Consistent with roles for GABA and glycine in the inhibitory circuitry of the SG was the presence of spontaneous synaptic potentials mediated by $\mathrm{GABA}_{\mathrm{A}}$ or glycine receptors. In five of six cells, at least a portion of spontaneous synaptic potentials was blocked by $\mathrm{GABA}_{\mathrm{A}}$ antagonists picrotoxin (100 $\mu \mathbf{M}, 2$ of 2) (Fig. $6 C$ ) or bicuculline $(30 \mu \mathbf{M}, 3$ of 4$)$ and four of seven cells had spontaneous synaptic potentials at least partly blocked by the glycine antagonist strychnine $(1 \mu \mathrm{M})$.

Opioid agonists inhibit the EPSP. ME caused an inhibition of the EPSP that was variable in magnitude. In 22 of 31 guinea pig SG cells, ME ( $3 \mu \mathrm{M})$ reduced the amplitude of the EPSP $42-$ $100 \%$ (Fig. $7 A$ ). In nine cells, ME reduced the amplitude of the EPSP $12 \%$ or less (Fig. $7 B$ ). Figure $7 C$ is a histogram of the inhibition of the EPSP by ME in guinea pig that illustrates the variability of the magnitude of the inhibition among neurons. As with the hypcrpolarization, inhibition of the EPSP by ME was mimicked by the $\mu$-opioid receptor agonist DAMGO (30
A.

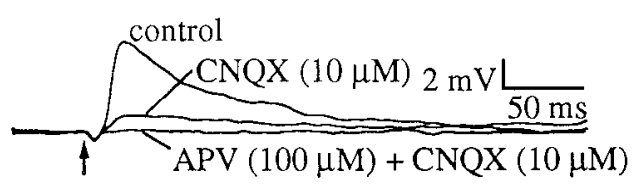

B.

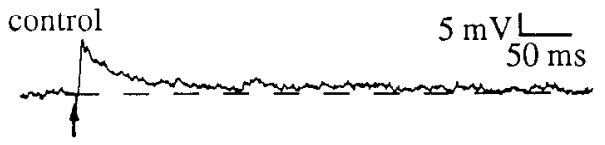

add picrotoxin $(100 \mu \mathrm{M})$ and strychnine $(1 \mu \mathrm{M})$

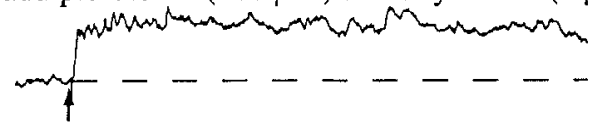

C.

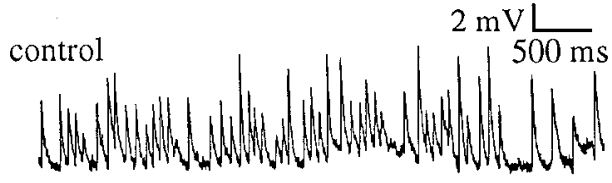

add picrotoxin $(100 \mu \mathrm{M})$

Figure 6. Effect of GABA and glycine receptor antagonists on synaptic potentials evoked by stimulating in the spinal trigeminal tract in guinea pig. $A$, Three superimposed traces showing that glutamate antagonists block the monosynaptic EPSP. CNQX decreases the EPSP and addition of APV to CNQX abulishes it. $B$, Perfusing the $\mathrm{GABA}_{\mathrm{A}}$ receptor antagonist picrotoxin and the glycine receptor antagonist strychnine leads to long-lasting synaptic activity in response to a single stimulus in the spinal trigeminal tract. $C$, Spontaneous synaptic potentials blocked by the $\mathrm{GABA}_{\mathrm{A}}$ receptor antagonist picrotoxin.

nм to $3 \mu \mathrm{M}, n=6$; Fig. $8 A$ ) with an $\mathrm{EC}_{50}$ of $52 \pm 46$ nм (Fig. $8 B)$. The error in the estimation of the $\mathrm{EC}_{50}$ and the slope of the concentration response curve $(0.91 \pm 0.79)$ results from the variability in the amount of inhibition observed between cells. In three cells in which the amplitude of the EPSP was reduced by $\mathrm{ME}$ and DAMGO, the $\delta$-opioid receptor agonist DPDPE (1 $\mu \mathrm{M})$ had no effect on the EPSP. Naloxone $(100 \mathrm{nM})$ reversed the inhibition of the EPSP by DAMGO ( $1 \mu \mathrm{M}, n=3)$. A higher concentration of DAMGO $(30 \mu \mathbf{M})$ overcame the block by naloxone $(n-2)$.

The effect of ME on the series of depolarizing synaptic potentials that followed the initial EPSP was examined by measuring the area under the synaptic potentials. In 13 cells, ME reduced the area by $37-83 \%$, with an average reduction of 68.3 $\pm 3.7 \%$. This indicates that the secondary actions on SG cells caused by primary afferent excitation are modulated by activation of opioid receptors.

To determine whether the inhibition of the depolarizing potential by MF was presynaptic or postsynaptic, the effect of ME on exogenously applied glutamate was examined in guinea pig SG slices (Fig. $8 C$ ). In three cells, ME ( $3 \mu \mathrm{M})$ reduced the EPSP by $89.3 \pm 6.9 \%$ while causing a $15.7 \pm 5.8 \%$ reduction in the depolarization produced by glutamate, perfused in the presence of TTX $(1 \mu \mathrm{M})$. These results suggest that ME is predominantly acting at a presynaptic site since there is little evidence for a postsynaptic interaction between $\mu$-opioid and glutamate receptors. Further evidence for a presynaptic site of action is the 
A.

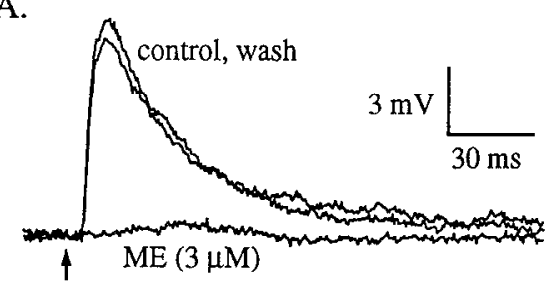

B.

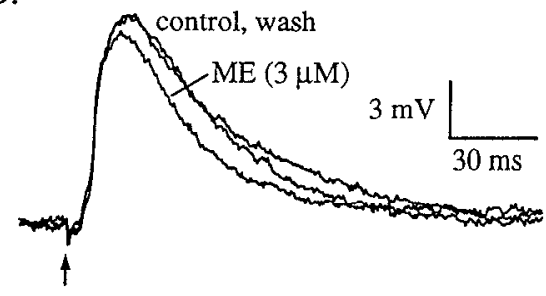

C. guinca pig

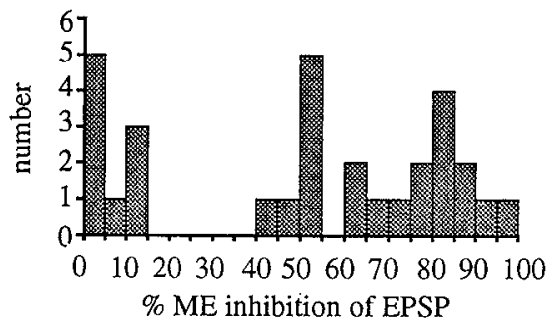

D. rat

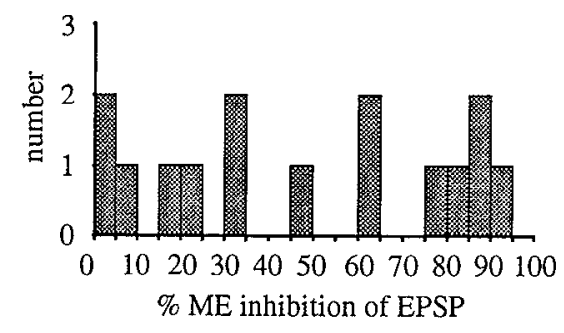

Figure 7. ME inhibits synaptic potentials evoked by stimulating in the spinal trigeminal tract. $A$, A synaptic potential inhibited by ME. Three superimposed traces are shown. The arrow indicates the time of the stimulus. $B$, A cell in which the synaptic potential was only slightly reduced by ME. $C$ and $D$, Histograms of the ME inhibition of the EPSP in guinea pig $(n=31)$ and rat $(n$ $=15$ ). observation that in three cells not hyperpolarized by $\mathrm{ME}$, the EPSP was still inhibited by $30 \%, 80 \%$, and $100 \%$.

Rat. As in guinea pig, stimulating the spinal trigeminal tract in the rat evoked a glutamate EPSP. The average amplitude of the fast EPSP was $10.8 \pm 0.7 \mathrm{mV}(n=30)$. Additional depolarizing synaptic potentials were observed in 3 of 10 cells. CNQX $(10 \mu \mathrm{M})$ reduced the amplitude of the synaptic potential by 81.7 $\pm 2.4 \%(n=12)$ and the CNQX-insensitive component of the synaptic potential was reduced $69.3 \pm 8.3 \%$ by APV $(30-100$ $\mu \mathbf{M}, n=4)$.

The amplitude of the glutamate EPSP recorded in rat SG neurons was reduced by opioid agonists. The reduction by $\mathrm{ME}$ ( $3 \mu \mathrm{M}$ ) was variable, ranging from 0 to $95 \%(n=16)$. A histogram of the inhibition of the EPSP among neurons in rat is shown in Figure $7 D$. As in guinea pig, the $\mu$-opioid receptor agonist DAMGO (300 nM to $1 \mu \mathrm{M}, n=3$ ) mimicked the inhibition by ME. Consistent with a presynaptic site of action of $\mathrm{ME}$, inhibition of the fast EPSP occurred in three cells not hyperpolarized by ME.

\section{Morphology of SG cells}

In guinea pig, 37 neurons that made up part of the pharmacological study were visualized by including biocytin in the recording pipette and subsequently reacting with HRP. The locations of these neurons are shown in Figure $9 A$. It should be noted that the locations of most cells were determined after drying the slices, which caused some distortion, particularly at the edge of the slice. Therefore, while it can be confirmed that the cells were in the $S G$, the mediolateral location of the cclls should be taken as an approximation.

The size of the soma ranged from 10 to $21 \mu \mathrm{m}$ (mean, 17.3 $+0.7 \mu \mathrm{m})$ in the rostrocaudal orientation and from 11 to 29 $\mu \mathrm{m}$ (mean, $17.8 \pm 0.6 \mu \mathrm{m}$ ) in the mediolateral orientation. Cells
Figure 8. $\quad \mu$-Opioid agonists mimic the ME inhibition of the EPSP evoked by stimulating the spinal trigeminal tract. $A$, The $\mu$-opioid agonist DAMGO mimics the inhibition of the EPSP by ME. The arrow indicates the time of the stimulus. $B$, Dose-response curve for the inhibition of the EPSP by DAM$\mathrm{GO}$ in guinea pig. $C$, ME has little effect on depolarization in response to exogenous glutamate. Data in $A$ and $C$ are from the same cell.
A.


B.



C.

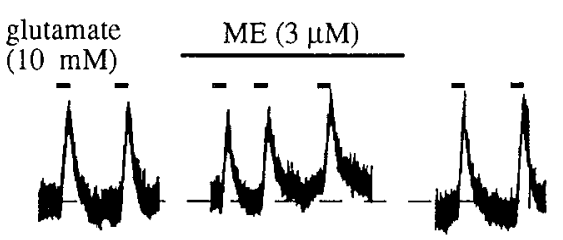



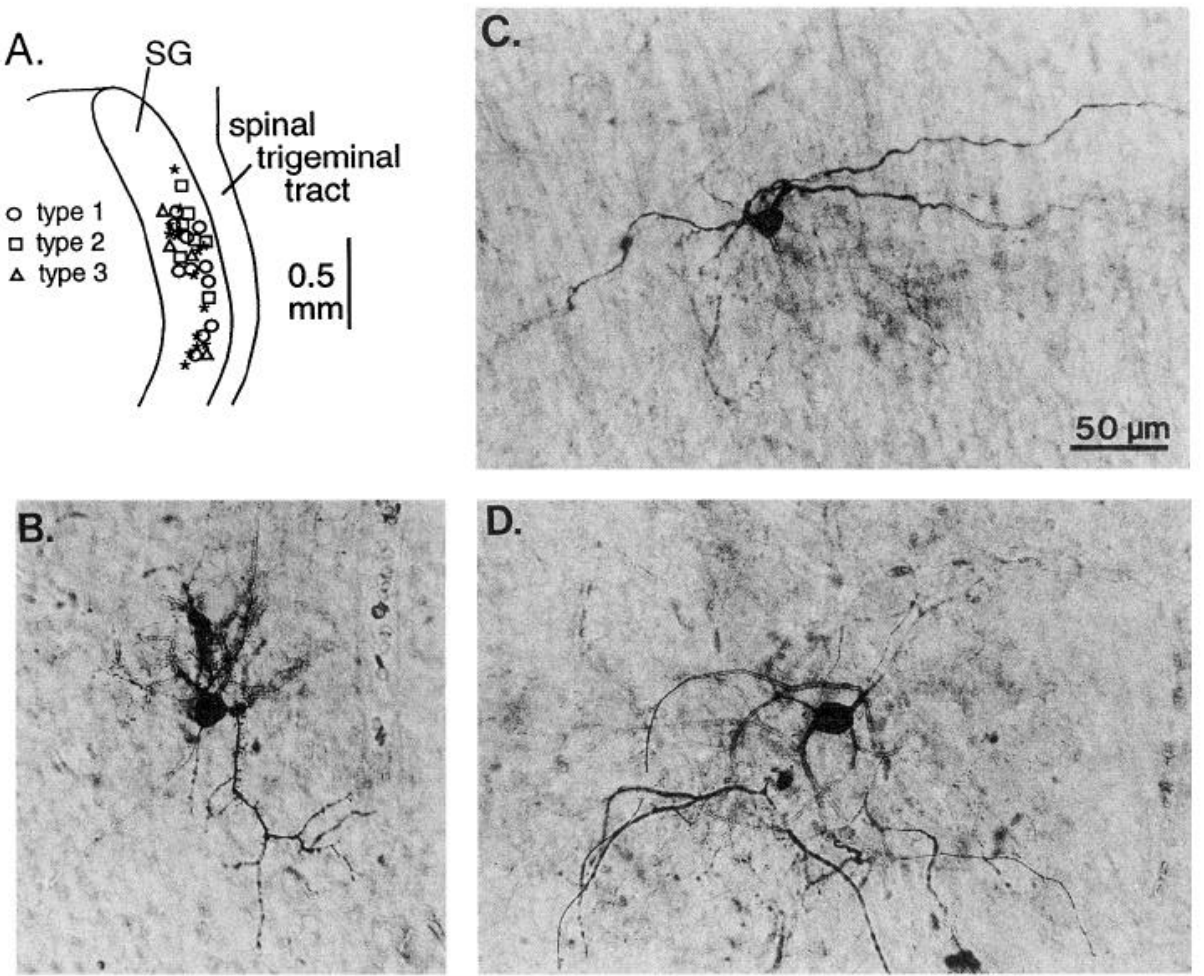

Figure 9. Morphology of SG neurons of the guinea pig spinal trigeminal nucleus pars caudalis. $A$, Locations of the filled cells. The open symbols refer to the morphological types of cells; asterisks represent neurons whose soma was visible but whose dendrites were not labeled well enough to characterize. $B-$ $D$ are cell types 1,2 , and 3 , respectively. In $B-D$, the lateral part of the slice is at the top and the rostral side to the left. The scale bar in $C$ applies to $B-D$. were divided into three groups based on the dendritic arbor. The characteristics of the cell types are summarized in Table 1.

Type 1 cells $(n=11$; Fig. $9 B)$ had $4-12$ fibers leaving the cell body. These branched moderately and were covered with spines. As can be seen from Table 1, most dendrites of type 1 cells did not extend farther than $115 \mu \mathrm{m}$ from the cell body. In four cases, the dendrites extended all directions from the cell body and in no particular orientation. In the other seven type 1 cells, the dendrites were oriented in a particular direction, with five arborizing medially and two predominantly laterally.

Type 2 cells ( $n=7$; Fig. $9 C$ ) had three to seven fibers leaving the cell body with few branches and, with one exception, lacked spines. The dendrites of type 2 cells extended for a longer distance than the dendrites of type 1 cells; about half extended farther than $200 \mu \mathrm{m}$ from the cell body. In two cases, the dendritic arbor extended rostrocaudally but the dendritic arbor of other cells showed no particular orientation.

Type 3 cells $(n=4$; Fig. $9 D)$ had features intermediate of types 1 and 2 . The cell body had three to six fibers that branched more extensively than type 2 cells. The dendrites of three cells were sparsely covered with spines. The dendrites of type 3 cells extended farther than those of type 1 cells, with few traveling more than $200 \mu \mathrm{m}$, but not farther than $250 \mu \mathrm{m}$. The dendrites of three of the four type 3 cells spread out medially from the cell body, with one or two fibers traveling laterally. In the other type 3 cell, fibers spread in all directions.

The location of the cells, by type, is shown in Figure $9 A$. No correlation was evident between the rostrocaudal or mediolateral location of the cell and cell type. There appears to be some differences in the electrophysiological characteristics between the different morphological types. The average input resistance of type 1 cells was $433 \pm 56 \mathrm{M} \Omega(n=6)$ and ranged from 200 to $600 \mathrm{M} \Omega$. The input resistances of type 2 cells were lower, averaging $157 \pm 27 \mathrm{M} \Omega(n=5)$ and ranging from 100 to 250 $\mathrm{M} \Omega$. The input resistances of two type 3 cells were 150 and 330 $\mathrm{M} \Omega$.

All types of neurons were hyperpolarized by ME. The amplitude of the hyperpolarization was highly variable among type 1 cells $(n=9)$, ranging from no effect in two cells to hyperpolarizations of at least $25 \mathrm{mV}(n=3)$. About half (five of nine) type 1 cells were hyperpolarized $8 \mathrm{mV}$ or less (average, $3.0 \pm$ 1.5) while the other four were hyperpolarized from 15 to $28 \mathrm{mV}$

Table 1. Morphological characteristics of SG cells

\begin{tabular}{|c|c|c|c|c|c|c|}
\hline & $\begin{array}{l}\text { Cell body size }(\mu \mathrm{m}) \\
\text { (rostrocaudal } \times \text { mediolateral) }\end{array}$ & $\begin{array}{l}\text { \# Fibers leaving } \\
\text { cell body }\end{array}$ & \multicolumn{4}{|c|}{$\begin{array}{l}\text { \# Fibers present at distances } \\
\text { from the cell body }(\mu \mathrm{m})\end{array}$} \\
\hline Type $1(n=11)$ & $17.5 \pm 1.0 \times 16.1 \pm 0.7$ & $6.6 \pm 0.7$ & $11.9 \pm 0.8$ & $7.4 \pm 1.0$ & $1.7 \pm 0.6$ & 0 \\
\hline Type $3(n=4)$ & $15.8 \pm 2.3 \times 23.3 \pm 2.6$ & $4.3 \pm 0.5$ & $7.8 \pm 1.3$ & $8.8 \pm 1.5$ & $8.8 \pm 1.7$ & $2.3 \pm 0.5$ \\
\hline
\end{tabular}

All cells $(n=34)$

$16.8 \pm 0.6 \times 17.4 \pm 0.6$

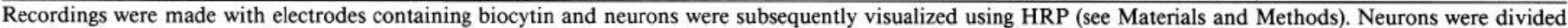
into three types based on their morphological characteristics (see Results). 
(average, $23.8 \pm 3.0$ ). The ME hyperpolarization of type 2 cells ( $n=6$ ) was more consistent, ranging from 14 to $25 \mathrm{mV}$ and averaging $17.4 \pm 1.7 \mathrm{mV}$. The hyperpolarization of three type 3 cells was at least $24 \mathrm{mV}$ in each case. EPSPs evoked by spinal trigeminal tract stimulation were recorded in all cell types.

\section{Discussion}

The actions of opioid agonists on neurons of the SG of the spinal trigeminal nucleus pars caudalis of guinea pig and rat were examined. Both the postsynaptic hyperpolarization and the presynaptic inhibition of transmitter release from primary afferent fibers were very similar in guinea pig and rat. Acting together, these two mechanisms mediate a potent inhibition of afferent input.

\section{Membrane hyperpolarization}

In both rat and guinea pig, ME hyperpolarized $86-90 \%$ of SG neurons by increasing potassium conductance. This effect of $\mathrm{ME}$ has been observed in numerous other preparations (Williams et al., 1982; Wimpey and Chavkin, 1991), including rat spinal cord SG (Yoshimura and North, 1983). The finding that the ME hyperpolarization was mediated by $\mu$ - and not $\delta$-opioid receptors is in agreement with results from intracellular recordings from dorsal horn neurons of an unidentified lamina in rat spinal cord slices (Jeftinija, 1988). The $\mathrm{EC}_{50}$ values of $72 \mathrm{~nm}$ for guinea pig and $70 \mathrm{~nm}$ for rat are close to what others have reported for DAMGO acting at $\mu$-opioid receptors to increase an inwardly rectifying potassium current (North et al., 1987; Christie and North, 1988). The naloxone $K_{D}$ of $1.4 \mathrm{~nm}$ for the DAMGO site is in agreement with the reported affinity of naloxone at the $\mu$-opioid receptor (Kosterlitz et al., 1972). The inhibition of neurons in the SG through hyperpolarization is one way in which opioid agonists could inhibit the transfer of noxious input to other central sites in the pain pathway.

\section{Inhibition of synaptic transmission}

Blocking activation of SG neurons by primary afferent fibers provides a second way in which opioid agonists might interfere with the perception of pain stimuli. Glutamate has been identified as a transmitter of primary afferent fibers terminating in the dorsal horn of the spinal cord in a number of studies (Jahr and Jessell, 1985; Yoshimura and Jessell, 1990). Glutamatemediated EPSPs were evoked by stimulating the spinal trigeminal tract rostral to the SG. Such stimuli evoked EPSPs that were always blocked by glutamate antagonists.

Glutamate-mediated EPSPs evoked by stimulating the spinal trigeminal tract were reduced by opioid agonists acting at $\mu-0-$ pioid receptors in both guinea pig and rat. The inhibition was most likely presynaptic since (1) the effect of opioid agonists on exogenously applied glutamate was small and (2) in some cells opioid agonists did not cause a hyperpolarization but did depress the EPSP.

The finding that opioid agonists decrease synaptic transmission between primary afferents and SG neurons is in agreement with several other studies. In dorsal horn neurons, dorsal root stimulation evoked EPSPs that were reduced by $\mu$-opioid receptor activation (Jeftinija, 1988). Using cocultured dorsal root ganglia and dorsal horn neurons from mouse, MacDonald and Nelson (1978) showed that EPSPs recorded in dorsal horn neurons following stimulation of dorsal root ganglia cells were reduced by opioid agonists. Hori et al. (1992) recorded from marginal neurons, lamina 1 , in a neonatal rat slice and found that spontaneous and evoked glutamate-mediated synaptic potentials were reduced by $\mu$-opioid receptor activation. Neurons of the marginal layer are thought to receive input from primary afferent fibers similar to SG neurons (Light and Perl, 1979). All three studies concluded opioid agonists caused inhibition by a presynaptic action.

The cell bodies that give rise to primary afferent fibers are in the trigeminal ganglion that is not included in the horizontal slice of Sp5c SG. The inhibition of transmitter release from primary afferent fiber stimulation is therefore likely to be an action at or near the terminals. The presence of $\mu$-opioid receptors on the terminals of primary afferent fibers and terminals is indicated by a loss of $\mu$-opioid receptors following dorsal root transection (Besse et al., 1992).

The degree of synaptic inhibition was highly variable in both species: some EPSPs were abolished completely while others were not affected. In addition to receiving afferent input related to noxious stimuli, many SG cells are also excited by innocuous stimuli (Light et al., 1979; Woolf and Fitzgerald, 1983). It has been reported that opioid agonists reduce the activation of dorsal horn neurons by noxious, but not innocuous, stimuli (Duggan et al., 1977; Hope et al., 1990). Human subjects have reported that opioid agonists relieve pain but have no effect on light touch (Behar et al., 1979; Wang et al., 1979). It may be that the opioidsensitive component of the EPSP was mediated by release of glutamate from afferent fibers activated by noxious stimuli.

It is unlikely that the secondary synaptic potentials seen in many cases represented a more slowly conducting group of fibers since the site of stimulation was within $1-2 \mathrm{~mm}$ of the cell. The action potentials of the most slowly conducting fibers propagate at $0.3 \mathrm{~mm} / \mathrm{msec}$ (Erlanger and Glasser, 1930). Therefore, the difference in latency between the fast and slow conducting fibers would amount to only a few milliseconds, which would not be possible to detect in our records. It is more likely that the secondary potentials result from polysynaptic excitation. The circuitry exists for such polysynaptic activation since the present results indicate that most $\mathrm{SG}$ cells are excited by primary afferent activation and it has been shown that the axons of many SG neurons arborize within the SG (Gobel, 1978; Bennett, et al., 1980).

Although opioid agonists decreased the polysynaptic potentials, it is not possible to identify a site of action. Opioid agonists may inhibit the interneurons directly by hyperpolarizing them, or may act at terminal regions to presynaptically reduce transmitter release. The latter action could happen at synapses between primary afferents and interneurons to reduce excitation of interneurons by primary afferents. Alternatively, it could occur at synapses between interneurons.

GABA and glycine appear to play an important role in the $S G$ to reduce recurrent excitation. Antagonists at $\mathrm{GABA}_{\mathrm{A}}$ and glycine receptors often led to a burst of EPSPs in response to a single stimulus, which previously had evoked a single EPSP. This observation suggests that normally inhibitory circuitry prevents recurrent excitation. In transverse slices of rat spinal cord SG, spontaneous inhibitory postsynaptic currents mediated by glycine and $\mathrm{GABA}_{\mathrm{A}}$ receptors have been observed (Yoshimura and Nishi, 1993). GABA and glycine present in cell bodies of SG neurons may be the source of this inhibitory tone (Todd, 1990; Todd and Sullivan, 1990).

The increase in recurrent excitation following blockade of inhibitory circuitry with bicuculline or picrotoxin and strychnine suggests the presence of excitatory interneurons. The iden- 
tity of the transmitter mediating the increased excitability is not known. However, glutamate receptor antagonists block recurrent excitation such that glutamate appears to be at least one possible candidate. It is also interesting to note that neurons containing glutamate have been found in the SG (Merighi et al., 1991).

\section{Morphology of $S G$ neurons}

All of the 34 biocytin-filled cells visualized using HRP were located within the translucent band of the SG and the cell somas of most were 15-20 $\mu \mathrm{m}$ in diameter. Three groups were identified based on morphological characteristics. Type 1 cells had spiny, branching dendrites, most of which did not extend more than $115 \mu \mathrm{m}$ from the cell body. These cells had high input resistances and responses to $\mathrm{ME}$ that ranged from no effect to large hyperpolarizations. The variable response to ME suggests that this group of cells may consist of more than one type of cell. The dendrites of type 2 cells lacked spines, branched infrequently, and extended farther than those of type 1 cells, often several hundred micrometers from the cell body. These cells had lower input resistances than type 1 cells and moderate to strong hyperpolarizations in response to ME. Type 3 cells were intermediate of types 1 and 2, having branching dendrites lightly covered with spines that extended farther than those of type 1. The dendrites of type 3 cells tended to arborize medially. These cells were strongly hyperpolarized by ME. EPSPs evoked by stimulating the spinal trigeminal tract were recorded in all cell types.

Attempts have been made to categorize SG cells based on their morphology (Gobel, 1978; Todd and Lewis, 1986). Some of the type 1 cells resemble stalked cells in the presence of short, spiny dendrites with a medial arborization, but these were not limited to the outer limit of the SG as was reported earlier, and the dendrites of other type 1 cells did not arborize medially. Several of the type 2 cells resembled islet cells (see Fig. 9C), with long, aspiny dendrites arborizing rostrocaudally, but this dendritic orientation was not present in most type 2 cells. The differences may be related to species, as the earlier studies used cat (Gobel, 1978) or rat (Todd and Lewis, 1986) and the present results are in guinea pig. However, others working in cat have had difficulty classifying SG neurons according to the above scheme (Light et al., 1979; Woolf and Fitzgerald, 1983).

These results demonstrate that opioid agonists acting at $\mu$-opioid receptors have multiple inhibitory actions in the SG of the spinal trigeminal nucleus pars caudalis. The similarity of $\mu$-opioid receptor-mediated effects in the SG of guinea pig and rat suggests that these actions have a common physiological role. The pre- and postsynaptic actions of $\mu$-opioid agonists within circuitry of the SG provide the means for potent inhibition of primary afferent signaling.

\section{References}

Behar M, Olshwang D, Magora F, Davidson JT (1979) Epidural morphine in treatment of pain. Lancet 1:527-529.

Bennett GJ, Abdelmoumene M, Hayashi H, Dubner R (1980) Physiology and morphology of substantia gelatinosa neurons intracellularly stained with horseradish peroxidase. J Comp Neurol 194:809827.

Besse D, Lombard MC, Besson JM (1992) Time-related decreases in $\mu$ and $\delta$ opioid receptors in the superficial dorsal horn of the rat spinal cord following a large unilateral dorsal rhizotomy. Brain Res 578: 115-121.
Christie MJ, North RA (1988) Agonists at $\mu$-opioid, $\mathbf{M}_{2}$-muscarinic and $\mathrm{GABA}_{\mathrm{B}}$-receptors increase the same potassium conductance in rat lateral parabrachial neurones. Br J Pharmacol 95:896-902.

Duggan AW, Hall JG, Headley PM (1977) Suppression of transmission of nociceptive impulses by morphine: selective effects of morphine administered in the region of the substantia gelatinosa. Br J Pharmacol 61:65-76.

Erlanger J, Glasser HS (1930) The action potential in fibers of slow conduction in spinal roots and somatic nerves. Am J Physiol 92:4382.

Giesler GJ, Menetrey D, Guilbaud G, Besson J-M (1976) Lumbar cord neurons at the origin of the spinothalamic tract in the rat. Brain Res 118:320-324.

Gobel S (1978) Golgi studies of the neurons in layer II of the dorsal horn of the medulla (trigeminal nucleus caudalis). J Comp Neurol 180:395-414.

Gobel S, Falls WM, Bennett GJ, Abdelmoumene M, Hayashi H, Humphrey E (1980) An EM analysis of the synaptic connections of horseradish peroxidase-filled stalked cells and islet cells in the substantia gelatinosa of adult cat spinal cord. J Comp Neurol 194:781-807.

Grudt TJ, Williams JT (1991) Opioids act at pre- and postsynaptic sites in the substantia gelatinosa of the spinal trigeminal nucleus in rat. Soc Neurosci Abstr 17:267.

Hope PJ, Fleetwood-Walker SM, Mitchell R (1990) Distinct antinuciceptive actions mediated by different opioid receptors in the region of lamina I and laminae $\mathrm{II}-\mathrm{V}$ of the dorsal horn of the rat. $\mathrm{Br} \mathbf{J}$ Pharmacol 101:477-483.

Hori Y, Endo K, Takahashi T (1992) Presynaptic inhibitory action of enkephalin on excitatory transmission in superficial dorsal horn of rat spinal cord. J Physiol (Lond) 450:673-685.

Jahr CE, Jessell TM (1985) Synaptic transmission between dorsal root ganglion and dorsal horn neurons in culture: antagonism of monosynaptic excitatory postsynaptic potentials and glutamate excitation by kynurenate. J Neurosci 5:2281-2289.

Jcftinija $S$ (1988) Enkephalins modulate excitatory synaptic transmission in the superficial dorsal horn by acting at $\mu$-opioid receptor sites. Brain Res 460:260-268.

Johnson SM, Duggan AW (1981) Evidence that opiate receptors of the substantia gelatinosa contribute to the depression, by intravenous morphine, of the spinal transmission of impulses in unmyelinated afferents. Brain Res 207:223-228.

Kosterlitz HW, Watt AJ (1968) Kinetic parameters of narcotic agonists and antagonists with particular reference to $\mathrm{N}$-allylnoroxymorphine (naloxone). Br J Pharmacol 33:266-276.

Kosterlitz HW, Lord JAH, Watt AJ (1972) Morphine receptor in the myenteric plexus of the guinea pig ileum. In: Agonist and antagonist actions of narcotic analgesic drugs (Kosterlitz HW, Collier HOJ, Villarreal JE, eds), pp 45-61. London: Macmillan.

Light AR, Kavookjian AM (1988) Morphology and ultrastructure of physiologically identified substantia gelatinosa (lamina II) neurons with axons that terminate in deeper dorsal horn laminae (III-IV). J Comp Neurol 267:172-189.

Light AR, Perl ER (1979) Reexamination of the dorsal root projection to the spinal dorsal horn including observations on the differential termination of coarse and tine fibers. J Comp Neurol 186:117-132.

Light AR, Trevino DL, Perl ER (1979) Morphological features of functionally defined neurons in the marginal zone and substantia gelatinosa of the spinal dorsal horn. J Comp Neurol 186:151-172.

MacDonald RL, Nelson PG (1978) Specific-opiate-induced depression of transmitter release from dorsal root ganglion cells in culture. Science 199:1449-1450.

Merchenthaler I, Maderdrut JL, Altschuler RA, Petrusz P (1986) Immunocytochemical localization of proenkephalin-derived peptides in the central nervous system of the rat. Neuroscience 17:325-348.

Merighi A, Polak JM, Theodosis DT (1991) Ultrastructural visualization of glutamate and aspartate immunoreactivities in the rat dorsal horn, with special reference to the co-localization of glutamate, substance $P$ and calcitonin-gene related peptide. Neuroscience 40:67-80.

North RA, Williams JT, Surprenant A, Christie MJ (1987) $\mu$ and $\delta$ receptors belong to a family of receptors that are coupled to potassium

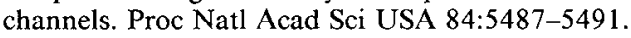

Sugiura Y, Lee CL, Perl ER (1986) Central projections of identified, unmyelinated $(C)$ afferent fibers innervating mammalian skin. Science 234:358-361.

Todd AJ (1990) An electron microscope study of glycine-like im- 
munoreactivity in laminae I-III of the spinal dorsal horn of the rat. Neuroscience 39:387-394.

Todd AJ, Lewis SG (1986) The morphology of Golgi-stained neurons in lamina II of the rat spinal cord. J Anat 149:113-119.

Todd AJ, Sullivan AC (1990) Light microscope study of the coexistence of GABA-like and glycine-like immunoreactivities in the spinal cord of the rat. J Comp Neurol 296:496-505.

Wang JK, Nauss LA, Thomas JE (1979) Pain relief by intrathecally applied morphine in man. Anesthesiology 50:149-151.

Williams JT, Egan TM, North RA (1982) Enkephalin opens potassium channels on mammalian central neurones. Nature 299:74-77.

Williams JT, Christie MJ, North RA, Roques BP (1987) Potentiation of enkephalin action by peptidase inhibitors in rat locus ceruleus in vitro. J Pharmacol Exp Ther 243:397-401.
Wimpey TL, Chavkin C (1991) Opioids activate both an inward rectifier and a novel voltage-gated potassium conductance in the hippocampal formation. Neuron 6:281-289.

Woolf CJ, Fitzgerald M (1983) The properties of neurones recorded in the superficial dorsal horn of the rat spinal cord. J Comp Neurol 221:313-328.

Yoshimura M, Jessell T (1990) Amino-acid-mediated EPSPs at primary afferent synapses with substantia gelatinosa neurones in the rat spinal cord. J Physiol (Lond) 430:315-335.

Yoshimura M, North RA (1983) Substantia gelatinosa neurones hyperpolarized in vitro by enkephalin. Nature 305:529-530. 